\title{
Sobre a questão da influência ameríndia na formação do Português do Brasil ${ }^{* 1}$
}

\section{INTRODUÇÃO}

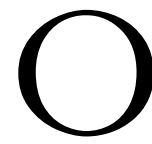

propósito deste artigo é trazer novamente para o fórum de discussões, com base em novos dados empíricos, a questão de uma possível influência de línguas indígenas ou das línguas gerais (de origem indígena) na formação do português do Brasil. Será defendido que essa formação se deu em virtude de a aprendizagem do português pela maioria da população do Brasil durante os séculos XVI, XVII e XVIII ter ocorrido como segunda língua em idade adulta. $\mathrm{O}$ artigo argumenta que isso ocorreu sem influência direta estrutural dessas línguas. Nessa linha de pensamento, qualquer influência ameríndia terá tido o mesmo efeito da influência das línguas africanas, faladas pelos escravos africanos e afro-descendentes, também adquiridas na mesma situação.

A hipótese de a causa da formação do português do Brasil ter sido o contato com as línguas indígenas e as línguas gerais parece, a princípio, muito plausível. A colonização portuguesa no Brasil ocorreu inicialmente na costa, tendo São Paulo (precisamente São Vicente e Piratininga, no leste do atual estado de São Paulo) como o limite sul e o norte dos atuais estados do Maranhão e do Pará como o limite norte. ${ }^{2}$ A língua falada no leste do atual estado de São Paulo, ao longo do Tietê, era o tupi. Do Rio de Janeiro para cima, a língua falada era o Tupinambá. O modo como se deu a colonização favoreceu nos extremos sul e norte dessa primeira área colonizada a formação de línguas gerais, de base indígena, tendo-se constituído uma língua geral paulista no sul, de base tupi, e uma língua geral amazônica no norte, de base tupinambá. Na longa extensão costeira intermediária, que vai do Rio de Janeiro ao Piauí, não 
houve tal formação. O que desfavoreceu a formação de línguas gerais nessa extensão da costa foi, de um lado, a continuada imigração portuguesa, com estabelecimento de famílias já formadas, o que não permitiu a situação de grande mestiçagem que se deu nos dois polos extremos da colonização em seu início, e, de outro, o extermínio dos povos indígenas, por massacre ou doenças. A formação de línguas gerais nos extremos norte e sul do domínio geográfico da colonização foi favorecida exatamente porque o afluxo de colonos portugueses nessas regiões foi menor do que o número de indígenas estabelecidos no local, e esses colonos em sua maioria eram homens sós e o povo indígena estava aberto ao contato. Dessa situação resultou um grande número de uniões entre homens portugueses e mulheres indígenas, cujos filhos tinham a língua indígena (tupi no sul e tupinambá no norte) como língua nativa. As línguas gerais surgiram com a generalização do uso das línguas originalmente indígenas por famílias que não contavam com a presença de indígenas. A respeito da formação da língua geral paulista, relata Rodrigues (1996, p. 8):

Na verdade, os índios tupis de São Paulo foram-se extinguindo como povo independente e culturalmente diverso, sobretudo por efeito da escravização intensiva, e sua língua passou a reproduzir-se essencialmente como idioma dos mestiços, isto é, dos mamelucos, ainda quando já não mais havia a interferência direta de indígenas nas famílias: a situação lingüística das famílias de portugueses casados com mamelucas devia então ser basicamente a mesma das famílias constituídas por mamelucos e mamelucas: falava-se correntemente a língua originalmente indígena e apenas o marido e, a partir de certa idade, os filhos homens eram bilingües em português (com domínio pleno desta língua se eram portugueses, com domínio provavelmente restrito em diferentes graus quando eram mamelucos). Nessa situação, a língua que falavam os paulistas já não mais servia a uma sociedade e a uma cultura indígenas, mas à sociedade e à cultura portuguesa. Essa progressiva mudança nas condições da língua, somada ao bilingüismo (de parte) dos homens, deve ter acarretado modificações em vários aspectos desta. Tal língua, generalizada na população paulista de meados do século XVII a meados do século XVIII, é que se chamou, em São Paulo, de língua geral. 
A colonização de São Paulo teve início no século XVI e o uso do tupi como língua materna pelos mestiços (mamelucos) perdurou até o final do século XVII, como confirmou o padre Antônio Vieira em 1694:

É certo que as famílias dos portuguezes e índios de São Paulo estão tão ligadas hoje humas às outras, que as mulheres e os filhos se criam mystica e domesticamente, e a língua que nas ditas famílias se fala he a dos índios e a portugueza a vão os meninos aprender à escola $[\ldots]]^{3}$

A língua geral paulista foi falada generalizadamente pela população de meados do século XVII a meados do século XVIII, como já mencionado. No norte, a colonização portuguesa somente teve início no século XVII, depois da expulsão dos franceses de São Luís e áreas vizinhas. O tupinambá foi falado até meados do século XVIII, quando foi extinta essa população indígena. A língua geral amazônica foi falada desde o século XVII e continua em uso até hoje, havendo dela registros dos séculos XVIII, XIX e XX.

A favor de a causa da formação do português do Brasil ter sido o contato com as línguas indígenas e com as línguas gerais temos, então, dois fatos. Primeiro, o fato de a língua da maioria das famílias de pais portugueses nos dois primeiros séculos da colonização portuguesa (séculos XVI e XVII) ter sido o tupi em São Paulo, e, no segundo século da colonização (século XVII), ter sido o tupinambá no Maranhão e Pará, sendo o português aprendido na escola pelas crianças, como disse o Padre Vieira. Segundo, o fato de que um desenvolvimento dessas línguas (a língua geral) continuou a ser usado, em São Paulo, de meados do século XVII a meados do século XVIII, e no Maranhão e Pará, do século XVII até hoje. Acrescem-se a isso dois outros fatos. Primeiro, no século XVII tanto a língua geral paulista quanto a língua geral amazônica ampliaram seu território geográfico. No caso da língua geral paulista, era essa a língua dos bandeirantes, que a levaram para Minas Gerais, sul de Goiás, Mato Grosso e norte do Paraná. No caso da língua geral amazônica, a expansão acompanhou a expansão portuguesa, que se deu ao longo do rio Amazonas e afluentes, tendo alcançado a Amazônia venezuelana e colombiana. Segundo, a troca da língua geral pelo português, como veículo de comunicação diária, somente se iniciou na primeira metade do século XVIII, tendo o país se tornado verdadeiramente lusófono somente a partir de meados do século XVIII. 
Apesar de haver pelo menos esses quatro fatos a favor dessa hipótese, há uma tendência quase unânime a se rejeitar a influência das línguas indígenas e das línguas gerais sobre o português, a não ser no vocabulário, onde se deu uma rica criação de empréstimos na toponímia e no léxico da flora e da fauna, entre outros campos semânticos. Rodrigues, em mais de uma publicação (RODRIGUES, 1986, 1996), tem defendido essa rejeição. Deve-se a ele a distinção entre duas línguas gerais, a paulista (com origem no tupi) e a amazônica (originada do tupinambá). Segundo ele, a influência estrutural se deu comprovadamente do português para as línguas gerais, e não do tupi, do tupinambá ou das línguas gerais para o português. A influência dessas línguas para o português, nos diz ele, parece ter se restringido ao vocabulário. Nesses trabalhos ele compara o português e o tupinambá quanto ao sistema de sons, às formas verbais, ao sistema de demonstrativos, à distinção de gênero e número, e a distinções lexicais, e, além disso, compara dados do tupinambá com dados da língua geral dela originada, mostrando como nesse processo de mudança lingüística houve uma aproximação em relação à gramática do português.

Teyssier (1997, p. 91) não só rejeita essa hipótese da influência ameríndia, mas até a ironiza, falando em "mania do tupi":

Durante longo tempo muitas das particularidades do português do Brasil foram explicadas como o resultado de influências ameríndias ou africanas. Do lado ameríndio, a fonte era essencialmente o tupi. Não contentes de identificar as raízes tupi da toponímia e do vocabulário, alguns queriam ver influência tupi em tudo, e explicavam pelo substrato tupi certos traços específicos da fonética, da morfologia e da sintaxe do português brasileiro. Espécie de resíduo filológico do indianismo romântico, a mania do tupi levou a exageros evidentes, a erros, a generalizações apressadas.

Dois fatores, pelo menos, se mostram contrários à influência exclusiva das línguas indígenas e línguas gerais: o fator quantitativo (percentual de falantes) e o fator duração do contato, como apontado por Mattos e Silva (2000). Quanto ao percentual de falantes, o número de indígenas só era numericamente relevante para justificar tal influência nos séculos XVI e XVII, tendo o número de escravos africanos e descendentes suplantado, e em muito, o da população de indígenas e descendentes a partir o século XVIII. No século XIX, houve ainda a grande imigração européia. Como a população indígena, de modo geral, 
não se integrou na vida das grandes cidades, é difícil ver que papel teria tido. Quanto ao fator duração do contato, deixando de lado a região amazônica, onde a língua geral foi de uso constante, no sul o tupi só foi falado em São Paulo até meados do século XVII e a língua geral paulista só foi falada no seu território expandido até meados do século XVIII.

No entanto, há ainda atualmente estudiosos defensores de uma influência indígena. Entre eles podemos citar Naro e Scherre (NARO, 1981, NARO e SCHERRE, 2000a) e Mattos e Silva (2003), que advogam uma confluência de fatores, entre eles as línguas gerais, como a causa da formação do português do Brasil. Esses autores não explicitam os pontos onde teria se dado essa influência ameríndia. Naro \& Scherre (2000a, p. 451) somente dizem que a língua geral tupi teria sido uma força adicional em interação com a deriva secular trazida da Europa e outras forças mais. Observe-se que estou pressupondo aqui uma influência além do empréstimo vocabular.

Passemos agora para a questão de uma possível influência do contato com as línguas africanas faladas pelos escravos (incluindo aí eventuais línguas francas africanas). A hipótese de ter havido uma tal influência, ao contrário da hipótese sobre influências ameríndias, tem encontrado não somente adeptos até os dias de hoje, mas também adeptos que apontam pontos específicos de influência. Guy (1981) usa fatos de concordância como evidência lingüística a favor da mesma. A tese que ele defende é que o português popular do Brasil (PPB) teve origem crioula. Isto é, o português do Brasil resultou do desenvolvimento de um pidgin ou crioulo colonial hipotético, de base lexical portuguesa. Essa idéia de ter havido um português crioulo também é expressa em Camara (1979, p. 28-29). que diz, ao falar do tráfico de africanos para os grandes latifúndios e centros urbanos do Brasil Colônia a partir do início do século XVII:

Eram contingentes das mais variadas nações negras, quer do grupo Bântu, quer de tribos não-Bântu, como especialmente os Yoruba. Reunidos à força num novo habitat, tinham necessariamente de criar uma língua de compromisso para intercurso. Parece que, desde muito cedo, a sua integração na sociedade branca, com estreitas relações com ela na qualidade de escravos ligados a todas as suas principais atividades, propiciou o desenvolvimento de um português crioulo, que uniu entre si os negros das mais diversas proveniências. Também 
tudo indica que se adaptaram com relativa facilidade ao uso da língua geral indígena, dando-lhe ainda mais estílo e expansão.

A argumentação de Guy, com base em dados de concordância, pode, em parte, ser resumida como a seguir: $1^{\circ}$ No PPB a marca de plural ocorre na primeira palavra do sintagma nominal, havendo variação quanto à ocorrência nas demais posições. Como esse fato não tem precedente na história da língua, não pode ser explicado em termos da hipótese da evolução natural. $2^{\circ} \mathrm{Nas}$ línguas africanas que podem ter influenciado na formação de um pidgin português no Brasil, a marca de plural ocorre no começo do sintagma nominal. Logo, há uma similitude de padrão entre o PPB e essas línguas, quanto à ocorrência da concordância. Essa similitude é ilustrada em pares como $o$ homem / os homem do PPB, de um lado, e pares como muntu (o homem) / banto (os homens), em diversas línguas banto, como o songo, e okùnrin (o homem) / àwon okùnrin (os homens) do yoruba (dados explicitados por Mussa, 1991), de outro. Em muntu / banto, mu- e ba-são prefixos indicadores de número - singular e plural, respectivamente, - e classe gramatical. Em okùnrin / àwon okùnrin, o singular é formado pelo morfema zero e o plural, pelo morfema àwon. $3^{\circ} \mathrm{A}$ similitude é evidência empírica a favor da hipótese de o PPB ter surgido por um processo de crioulização, uma vez que não pode ser explicada em termos de evolução natural. $\mathrm{O}$ autor não se pronuncia acerca de possível influência das línguas indígenas ou das línguas gerais nem nesse trabalho nem em trabalho posterior sobre o mesmo tema (GUY, 1989).

Por sua vez, Mattos e Silva (2003, p. 224-225) credita à influência das línguas banto e kwá (entre essas últimas, sobretudo o ewe-fon e o yorubá), juntamente com a influência do conservadorismo, a configuração atual do sistema vocálico brasileiro, que teria mantido a mesma configuração do sistema vocálico português pré-setecentista.

Teyssier (1997, p. 91-92), colocando-se em posição diametralmente oposta, se manifesta contrário a uma influência africana, do mesmo modo que se manifesta contra a influência ameríndia:

Depois do tupi, foi a vez das línguas africanas. Como se os autênticos africanismos do vocabulário brasileiro não bastassem, passou-se a sentir a presença africana em toda a parte, particularmente na fonética. Em verdade, não é impossível que os escravos africanos 
tenham contribuído para dar ao português americano uma certa languidez crioula. Mas aqui trata-se de coisa muito diversa de substrato. As dificuldades que os aloglotas têm de articular uma nova língua fazem precipitar certas transformações provocadas pela deriva dessa língua. Os filólogos portugueses davam, geralmente, o seu aval a esta visão das coisas: para Gonçalves Viana, por exemplo, os "erros" brasileiros sobre a colocação dos pronomes átonos são crioulismos, como também o são a maioria das particularidades fonéticas do português brasileiro.

Se se defende que houve influência exclusivamente indígena ou exclusivamente africana, algumas questões têm de ser esclarecidas. Uma delas é a do domínio geográfico, apontada por Mattos e Silva (2000). Essa questão diz respeito ao fato de que as línguas africanas cobriam uma certa extensão do território brasileiro, e as línguas indígenas, outra, havendo ainda variação no domínio de acordo com o período histórico. Para contornar esse problema, relativamente à influência do contato com as línguas africanas, Mattos e Silva (2000, 2003) levou em conta a mobilidade geográfica e social da população africana e de afro-descendentes, do século XVI ao século XIX, apontada por Mattoso (1990) em sua obra sobre os escravos no Brasil. Evidentemente, essa mesma linha de argumentação não é, pelo menos à primeira vista, plausível para a população falante das línguas gerais, uma vez que não houve língua geral no longo território costeiro brasileiro que vai do Rio de Janeiro ao Piauí (como já mencionado, nessa região os índios foram praticamente exterminados, ou por genocídio ou por doenças, e para lá houve continuada imigração de portugueses; além disso, para lá houve também grande afluxo de escravos africanos). Contudo, Rodrigues (comunicação pessoal) apontou haver uma grande semelhança estrutural entre as línguas tupi e tupinambá. Dada essa semelhança estrutural, o mesmo tipo de gramática, subjacente a essas línguas, estava também presente na costa leste, a partir do Rio de Janeiro, e nordeste, habitada pelos tupinambás, antes de sua extinção no século XVII. Portanto, como houve contato lingüístico nessa região (algum contato certamente houve, até com formação de uniões, mesmo que não intenso), uma eventual influência de línguas indígenas poderia em princípio ser defendida, independentemente de explicação por mobilidade geográfica. 
Há, no entanto, um problema crucial para uma tal proposta - sabe-se que a mudança lingüística ocorre quando se dá a aquisição da língua por novas gerações que depreendem dos dados a que estão expostas gatilhos que levam à formação de uma nova gramática. No caso dos falantes paulistas dos séculos XVI e XVII, e dos falantes do norte do século XVII, fica claro que havia todas as condições para a formação de uma nova gramática, nas famílias bilíngües formadas de pais portugueses e mães índias - o português era adquirido pelas crianças como segunda língua, depois de adquirido o tupi (São Paulo) ou o tupinambá (Maranhão e Pará). O mesmo valia para os falantes das línguas gerais que fossem adquirir o português - as línguas gerais eram nativas e o português, a segunda língua. O problema é que não houve, na costa do Rio até o Piauí, uma situação nem minimamente comparável, dado que o contato não foi do mesmo tipo, uma vez que não houve mestiçagem numerosa entre índios e portugueses (apesar de, certamente, ter havido alguma), o que impediu a formação de bilingüismo generalizado. $\mathrm{O}$ mesmo tipo de argumento vale para a suposta influência africana - apesar da mobilidade geográfica e social da população africana e de afro-descendentes do século XVI ao século XIX, ela certamente não chegou a cobrir todo o vasto território nacional. Voltarei a essa questão da mobilidade e do bilingüismo na Seção 3.1.

Consideremos agora a hipótese de influência conjunta, ameríndia e africana. Como já observado, essa hipótese é defendida por Mattos e Silva (2000, 2003). ${ }^{4}$ Apesar disso, a autora se estende mais na argumentação acerca da influência das línguas africanas. Aponta três diferentes tipos de evidência a favor da influência das línguas africanas: (a) os dados de demografia histórica, que mostram que no Brasil do final do século XVI os escravos seriam $42 \%$ da população total e, às vésperas da Independência, 1818, mais de 50\%, o que indica que "a população escrava, africana e crioula, ficou, no período colonial, no patamar de 50\%", (b) a mobilidade geográfica e social da população africana e de afro-descendentes e (c) "a ausência de escolaridade desse numeroso contingente populacional", uma vez que a educação escolar do escravo "era totalmente proibida no Brasil até para os forros e isso perdura ainda na $2^{\text {a }}$ metade do século XIX" (2000, p. 17). Da ausência de escolaridade (terceiro fator) se segue o fato de a grande massa da população adulta de origem africana ter adquirido o português como segunda língua em condições adversas. Essa seria a explicação para a mudança. Os dois primeiros fatores explicariam a "generalizada difusão da língua portuguesa no território brasileiro". 
Naro \& Scherre (2000a), também, como já mencionado, adeptos da hipótese de mudança por confluência de fatores, explicitam o que entendem por uma tal confluência. Segundo sua hipótese, o gêrmen da mudança já veio com o português trazido para o Brasil e o contexto brasileiro só reforçou uma mudança já em curso. Isto é, o português apresentava uma deriva secular e no Brasil uma série de fatores interagiu para reforçar alguns aspectos dessa deriva original. Esses fatores foram: (a) a pidginização - isto é, (A) o uso pidginizado do português pelos portugueses em seu contato (i) com africanos, tanto na Europa quanto na África, desde o século XVI, sendo esse uso chamado de língua de preto ou português de preto, e (ii) com os índios, uso chamado de português de índio, e (B) o uso da língua geral tupi - e (b) a aprendizagem imperfeita (expressão que Naro \& Scherre 2004 evitam, substituindo-a por aquisição como segunda língua por adultos). Existe uma grande diferença entre a proposta de confluência de fatores de Mattos e Silva, de um lado, e a de Naro (1981) e Naro \& Scherre (2000a), de outro: na proposta de Naro e Scherrre, não há reestruturação lingüística provocada por influência de línguas africanas (e nem tampouco de línguas de origem indígena). A hipótese de reestruturação lingüística pelo contato com as línguas africanas, presente na obra de Mattos e Silva, é a tese defendida por Guy $(1981,1989)$ (e também por HOLM 1992 e BAXTER e LUCCHESI, 1997). Para Naro e Scherre (SCHERRE, c.p.), até prova em contrário, a influência ameríndia ou africana seria equivalente. Um dos pontos cruciais da argumentação desses autores e específico de sua proposta é a defesa de que todas as configurações estruturais existentes hoje no português do Brasil já existiam nas variedades do português europeu que vieram para o Brasil (V. NARO e SCHERRE, 2004). Finalmente, outro fator enfatizado por essa proposta como causador da mudança é o social - "o afrouxamento das amarras sociais, no sentido bastante natural do termo, tendo em vista a formação de uma nova sociedade" (SCHERRE, c. p.). Nas palavras dos autores (2004):

[O] português brasileiro é o resultado da deriva secular inerente na língua trazida de Portugal, ampliada no Brasil pela exuberância do contato de adultos, falantes de línguas das mais diversas origens, e da nativização desta língua pelas comunidades formadas por estes falantes, em um contexto em que a norma lingüística natural - que permeia as interações - apresentava mais graus de liberdade. 
O problema para essa hipótese é explicar em termos lingüísticos específicos o que significa dizer (a) que o gêrmen da mudança estava estritamente no português trazido para o Brasil e (b) que a exuberância do contato dos adultos aloglotas ampliou a deriva. Do mesmo modo, seria preciso explicar, em termos estritamente lingüísticos, como e por que a nativização do português no Brasil, num contexto de adultos aloglotas, provocou mudanças tão precisas quanto as que ocorreram no português. Os autores tampouco explicam em detalhe qual o tipo de influência das línguas ameríndias e africanas, já que não se trata, segundo eles, de causação de mudança estrutural.

Dizer que foi uma influência conjunta não é por si só explicativo. Essa hipótese na verdade levanta outra questão (V. MATTOS E SILVA, 2000): Como e por que diferentes tipos de contato causaram a mudança, e, sobretudo, uma mudança relativamente uniforme e generalizada, num país de dimensões continentais como o Brasil? ${ }^{5}$ Certamente o processo de aquisição do português como segunda língua, por adultos, está por trás da explicação, como defende Mattos e Silva. No entanto, é precisar entrar em mais detalhe e explicar como e por que isso se dá e como e por que diferentes tipos de contato podem levar a um mesmo tipo de mudança.

No resto deste trabalho vou procurar mostrar pontos de convergência entre o tupi e a língua geral paulista, de um lado, e o português contemporâneo do Brasil, de outro. Oque é importante é que os pontos de convergência que serão mostrados entre essas línguas ameríndias e o português do Brasil são pontos de divergência estrutural entre o português do Brasil e o português europeu contemporâneos. O meu objetivo não é demonstrar que tem de ser revista a rejeição automática à tese de influência das línguas indígenas e línguas gerais na formação do português do Brasil. Antes, o objetivo é levar à reflexão sobre os efeitos do contato lingüístico na mudança e procurar mostrar que, apesar de incríveis convergências entre propriedades das línguas ameríndias e do português do Brasil contemporâneo, a causa da mudança pode estar no processo de aprendizagem do português como segunda língua, e não na influência direta estrutural de uma língua sobre a outra. Esta é a posição defendida por este artigo. Essa posição se aproxima bem das de Teyssier (1997), Mattos e Silva (2000, 2003) e Naro \& Scherre (2000a, 2004), quanto à proposta de o fator causador ter sido a aprendizagem como segunda língua, por adultos. Contudo, a minha análise se diferencia por dar mais ênfase a esse fator e por apresentar uma proposta concreta a respeito do que esse tipo de aquisição representa 
lingüisticamente, numa análise lingüística interna dos fatos. A análise também se diferencia da proposta de Naro e Scherre em outros pontos, a que retornarei na Seção 3.1

\section{A CATEGORIA PESSOA EM LÍNGUAS AMERÍNDIAS}

\subsection{Tupi}

A língua tupi, como já apontado, foi a língua falada pelos grupos indígenas de parte do litoral sudeste brasileiro, precisamente do leste do atual estado de São Paulo, ao longo do Tietê. Foi documentada no século XVI por Anchieta e no século XVII por outros estudiosos.

Anchieta (1595) observou uma relação entre posicionamento sintático e função e uma relação entre seleção de estrutura e seleção de pessoa gramatical. De um lado, o objeto pronominal é sempre pré-verbal, como em (1):

(1) xé oro-juká

(Anchieta, folha 37) eu te mato

Além disso, fica sempre mais próximo de $\mathrm{V}$ do que um sujeito igualmente pronominal. De outro lado, a contigüidade com relação ao verbo é relevante para a interpretação da função da posição. Por exemplo, xé é um pronome que pode ser um nominativo ou um acusativo de primeira pessoa, e a sua posição é que indica a função, como em (2):
a. xé oro-juká
(Anchieta, folha 37)
eu te mato
b. xé juká
(Anchieta, folha 12)
me matam
c. xé juká Pedro
(Anchieta, folha 37)
me mata o Pedro
O Pedro me mata.

Por sua vez, em certas circunstâncias, há um cruzamento entre interpretação de pessoa gramatical e interpretação da estrutura sintática. Por exemplo, o prefixo pronominal oro- é um acusativo de $2^{\mathrm{a}}$ pessoa. Na forma verbal [oro- V], esse prefixo, um objeto de $2^{\mathrm{a}}$, implica necessariamente um sujeito de 
$1^{\mathrm{a}}$ pessoa. Essa $1^{\mathrm{a}}$ pessoa pode, ou não, ser manifesta, mas é sempre interpretada. Isso está resumido em (3) e ilustrado em (1), repetido abaixo:

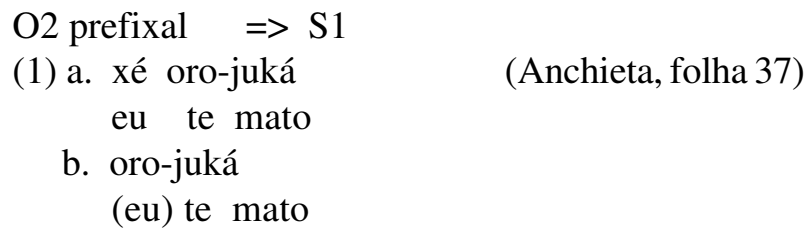

Uma característica do tupi, assim como de outras línguas indígenas brasileiras, é a total lacuna lexical para pronomes de terceira pessoa, como formas livres. As formas pronominais livres, sempre tônicas, são de $1^{\mathrm{a}}$ ou $2^{\mathrm{a}}$ pessoa, estritamente. Isso pode ser visto no Capítulo V da Gramática de Anchieta (folhas 10-11), intitulado 'Dos pronomes', onde ele somente arrola pronomes de $1^{\mathrm{a}}$ e $2^{\mathrm{a}}$ pessoas. A $3^{\mathrm{a}}$ pessoa é expressa sob a forma de NPs e sob a forma de prefixo nominativo (o-) na morfologia verbal (o-juká= ele mata). Esses prefixos indicadores de sujeito existem também para a $1^{\mathrm{a}}$ e $2^{\mathrm{a}}$ pessoas. Anchieta (folha 20) rotula tais prefixos de 'artigos' (artículos). Quando há um objeto de $3^{\mathrm{a}}$ pessoa, a morfologia verbal indica a presença dessa função com um morfema relacional, como ilustrado em (4), onde $i$-é o morfema relacional.

a- i- $\quad$ juká Pedro
eu R(a ele) mato Pedro
'Eu mato Pedro'
(Anchieta, folha 36)
'Eu mato Pedro'

Esse tipo de morfema é examinado em profundidade em Grannier (2005), que assim o caracteriza (Grannier 2005: 130): ${ }^{6}$

[Os prefixos relacionais] não assinalam nem concordância nem referência pronominal definida por propriedades lexicais. $\mathrm{O}$ vínculo que eles estabelecem é definido através da referência à função sintática do antecedente. Ou seja, os prefixos relacionais são próformas que remetem à função dos constituintes sintáticos da sentença, o que permite identificar indiretamente o antecedente do prefixo como o referente expresso nessa função.

Na maioria das ocorrências, o constituinte sintático no qual se identifica o antecedente do prefixo relacional é o argumento externo [à morfologia verbal] da própria função expressa internamente [na morfologia verbal], no predicado, pelo prefixo relacional. 
Dado que (a) os objetos pronominais são sempre pré-verbais, (b) as formas pronominais livres são estritamente de $1^{\mathrm{a}} \mathrm{e} 2^{\mathrm{a}}$ pessoas gramaticais, (c) os prefixos de $3^{\text {a }}$ pessoa são sempre, e somente, nominativos e (d) em formas com o prefixo $i$-, relativo a um objeto direto de $3^{\text {a }}$ pessoa, tem-se um morfema relacional e não uma forma pronominal, conclui-se que os objetos pronominais são sempre préverbais, sempre formas livres e somente de $1^{\mathrm{a}}$ e $2^{\mathrm{a}}$ pessoas.

\subsection{Línguas Gerais}

A língua geral paulista está pouco documentada. Como observa Rodrigues (1996, p. 8), o documento principal que se tem é um dicionário anônimo de verbos, publicado em von Martius (1867, p. 99-122) sob o título de Tupi Austral. Felizmente o autor fornece exemplos de verbos flexionados de tipo sentencial. Esses exemplos, como os em (5), mostram que a língua geral paulista manteve a mesma estrutura pronominal que se observava no tupi.

(5) acauçub [ortografia no Glossário] açauçub [ortografia que se esperava]
A. s- awsub
eu R- amar
'Eu o amo'

(6) chérenóin bonhêenga che r- enõy mbo- nhe'eng eu R- chamar CAUS falar 'Me chamam para testemunhar'

Os exemplos mostram também ocorrência da negação como prefixo verbal (nd-), exatamente como no tupi.

Infelizmente, não existem exemplos com sujeito de $1^{\mathrm{a}}$ pessoa e objeto de $2^{\mathrm{a}}$, que poderiam mostrar se se manteve o jogo pronominal em que a presença do objeto de $2^{\mathrm{a}}$ implica a interpretação do sujeito como de $1^{\mathrm{a}}$, quer este último esteja manifesto ou não.

Na língua geral amazônica, no entanto, não somente desapareceu o jogo pronominal, mas também houve mudança na estrutura pronominal. Esta língua na verdade se aportuguesou, mantendo formas do tupinambá mas com uso como no português (V. RODRIGUES, 1996). Portanto, a língua geral paulista foi mais conservadora do que a amazônica. 


\section{PROPRIEDADES DISTINGUIDORAS DO PE E DO PB E COMPARTILHADAS ENTRE O PB E LÍNGUAS AMERÍNDIAS}

\subsection{Objetos Pronominais}

\subsubsection{O Sistema de Clíticos do PE e do PB}

O português do Brasil coloquial restringiu a ocorrência dos clíticos pronominais acusativos à posição pré-verbal e limitou sua interpretação às $1^{a}$ e $2^{\mathrm{a}}$ pessoas.

A ocorrência basicamente pré-verbal dos clíticos no português do Brasil distingue essa gramática da do português europeu, uma vez que no português europeu a ocorrência é tanto proclítica quanto enclítica, dependendo da estrutura léxico-sintática da sentença (como se sabe, fatores como a presença de quantificadores, palavras Qu- e negação, entre outras, são cruciais para a colocação pronominal no português europeu). ${ }^{7}$

A limitação da interpretação resultou no contraste em (7)-(8) entre o português coloquial do Brasil e o português europeu, para as formas acusativas do singular:
(7) Repertório Clítico Acusativo Singular do PE:
$1 \mathrm{~S} \quad 2 \mathrm{~S} \quad 3 \mathrm{~S}$
(8) Repertório Clítico Acusativo Singular do PCB: me te,o,lhe -

Os exemplos em (9) são conseqüência dessa restrição:
a. Eu lhe vi (PE: *)
b. Eu o vi
$(\mathrm{PE}: *)$

De um lado, a próclise é a ordem natural no português coloquial do Brasil. De outro lado, os clíticos em (9) são interpretados como $2^{\mathrm{a}}$ pessoa, e não como $3^{\text {a }}$. No português europeu esses exemplos são agramaticais por diferentes razões: (9a), em virtude de 'lhe' não ser licenciado como acusativo nessa gramática e de a ênclise ser exigida quando o sujeito é de tipo referencial e a sentença, matriz e afirmativa, e (9b), por esta última razão. As formas gramaticais no português europeu corrrespondentes a $(9 a, b)$ são as em $(10 a, b)$, respectivamente: 

(10)
a. Vi-o.
(PE: OK)
b. Eu vi-o.
(PE: OK)

De qualquer modo, quando as formas 'lhe' e 'o' são gramaticais (como em Não lhe dei isso./ Não o vi.) podem ter leitura de $2^{\mathrm{a}}$ ou $3^{\mathrm{a}}$ pessoa.

A mudança ocorrida no sistema de clíticos pronominais do português coloquial do Brasil afetou não somente a interpretação semântica desses itens, mas também a sua interpretação gramatical. Isso se vê em (11) e (12), que retomam (7) e (8) acrescentando-lhes as formas dativas. Esses repertórios mostram que 'lhe' foi acrescido ao sistema acusativo do português do Brasil vernacular:
(11)
a. Repertório Clítico Acusativo Singular do PE me
$1 \mathrm{~S} \quad 2 \mathrm{~S}$
$3 \mathrm{~S}$
b. Repertório Clítico Dativo Singular do PE:
me te, lhe lhe
a. Repertório Clítico Acusativo Singular do PCB:
b. Repertório Clítico Dativo Singular do PCB:
me te,o,lhe -
me te, lhe

Quanto à função, o aspecto inovador da gramática do português coloquial do Brasil foi a interpretação acusativa para as formas que tinham interpretação dativa, de modo que 'lhe', uma forma originalmente dativa (Eu lhe dei o livro.), passou a ser licenciada como dativa $e$ acusativa ( $E u$ lhe vi.). Essa mudança afetou somente os clíticos que eram originalmente de $3^{\mathrm{a}}$ pessoa, pois os de $1^{\mathrm{a}}$ e $2^{\mathrm{a}}$ já aceitavam interpretação acusativa (Ele me/te viu) $e$ dativa (Ele me/te deu o livro.).

Houve, então, uma regularização do sistema, exceto para a forma 'o', que se mantém como acusativa, somente. No entanto, essa forma não é a preferencial para referência à segunda pessoa acusativa, sendo 'te' a preferencial, seguida de 'lhe'.

\subsubsection{Como Explicar o Funcionamento dos Objetos Pronominais no PE, PCB, Tupi e Língua Geral Paulista?}

Como explicar as diferenças morfossintáticas entre os clíticos do português europeu e do português do Brasil? Segundo a análise que faço, a gramática do português do Brasil licencia a linearização dos argumentos com traços extensionais. Isso tem de ser verdadeiro, porque no português coloquial 
do Brasil os clíticos passaram a ocorrer em posição pré-verbal e com leitura necessariamente de $1^{\mathrm{a}}$ ou $2^{\mathrm{a}}$ pessoa, e os traços de pessoa são extensionais. No português europeu não pode estar ocorrendo o mesmo, dado que não há correlação entre posição estrutural e interpretação de pessoa para os clíticos.

Por outro lado, há no português europeu formas clíticas de $3^{\mathrm{a}}$ pessoa especializadas para Caso. Logo, deve haver verificação de traço de Caso na sintaxe. Minha conclusão é que o português europeu recobre com traço específico de Caso a informação de pessoa dos clíticos porque não licencia na sintaxe a leitura extensional. Mais claramente, um modo de a língua assegurar que o posicionamento dos clíticos não é licenciado por traço de pessoa é encapsular os traços de pessoa com um envólucro de traço de Caso.

O que diferencia os sistemas clíticos do português europeu e do português do Brasil aproxima os sistemas pronominais do português do Brasil, do tupi e provavelmente da língua geral paulista: por exemplo, tanto na gramática do português coloquial do Brasil quanto na do tupi e provavelmente da língua geral paulista, objetos pronominais (clíticos no caso do PCB) só podem ocorrer proclíticos ao verbo e são somente de $1^{\mathrm{a}}$ e $2^{\mathrm{a}}$ pessoas. $\mathrm{O}$ que os distingue, no entanto, é o jogo pronominal entre pessoas do sujeito e do objeto, que existe no tupi - ilustrado em (3) e (1) - (e talvez também na língua geral paulista), mas não no português do Brasil, e que, por sinal, se perdeu na língua geral amazônica. Mas a propriedade de usar informação de pessoa gramatical para a linearização na sintaxe, mesmo que sob forma diferente na execução, é fato compartilhado entre o português coloquial do Brasil e aquelas citadas línguas ameríndias. Portanto, o português coloquial do Brasil passou a se assemelhar ao tupi e à língua geral paulista quanto ao uso de traços de pessoa para a construção da estrutura morfossintática, uma propriedade totalmente ausente do português europeu.

\subsection{Deslocamento Sintático de Subconstituinte do Argumento Interno}

\subsubsection{Licenciamento de Sujeito pelo Traço Categorial no PB e Temático no PE}

Esta seção apresenta evidência de que houve de fato uma fixação do plano extensional pelo português do Brasil para efeito de licenciamento de sujeito 
oracional, em contraste com o português europeu. A evidência é o fato de o português do Brasil licenciar sujeitos por meio da leitura extensional da expressão nominal, pela verificação do seu traço categorial, e o português europeu, por meio da leitura temática da expressão nominal, pela verificação do seu traço temático. Em outras palavras, o português do Brasil faz a verificação de traços na interface extensional da gramática internalizada onde lê a propriedade "ser expressão nominal completa" (no sentido de ter propriedade extensional e informação lexical), e o português europeu a faz na interface intensional, onde lê as propriedades que levam à interpretação temática. ${ }^{8}$

Um tipo de construção reveladora da diferença de planos entre o português europeu e o português do Brasil é a em (13), que é gramatical no português do Brasil, mas não no português europeu, onde somente (14a,b) podem ser geradas:

(13) O meu carro furou o pneu.

(PE: *, PB: OK)
a. Furou o pneu do meu carro.
(PE: OK, PB: OK)
b. O pneu do meu carro furou.
(PE: OK, PB: OK)

O que é especial em (13) é que tanto a posição de sujeito quanto a de objeto são ocupadas por subconstituintes do argumento interno (o objeto semântico, o tema). Essa sequiência é agramatical no português europeu porque somente parte do argumento interno foi alçada para a posição de sujeito, tendo a outra ficado na posição de objeto. Como (14a,b) mostram, caso todo o argumento interno ou permaneça na posição de objeto ou seja alçado para a posição de sujeito, o resultado é gramatical no português europeu. Esses fatos revelam que o sistema computacional do português europeu preenche as posições de sujeito e objeto levando em conta a informação que identifica os argumentos de $\mathrm{V}$ como tais e só pode preenchê-las com argumentos completos. Logo, no português europeu o preenchimento se faz por meio do uso do traço caracterizador do argumento como um todo, não sendo permitido exame da sua estrutura interna.

O que a gramaticalidade de (13) revela a respeito do português do Brasil, é que o seu sistema computacional pode examinar o interior do argumento interno, lá encontrar dois diferentes subconstituintes, e licenciá-los como sujeito e como objeto da mesma sentença, não sendo necessário ficar no nível de 
identificação dos argumentos como tais. Em (13), o argumento interno expressa uma relação todo/parte. O que concluo é que nessa relação os dois subconstituintes são licenciados como sujeito e objeto da mesma oração porque, entre outras condições, ambos têm propriedades completas de expressões nominais (cada um tem sua estrutura léxico-conceptual (LC) e cada um tem sua extensão definida). A relação todo/parte se distingue da relação de argumento por independer totalmente de qualquer núcleo, ao passo que a relação de argumento depende de um núcleo lexical (todo argumento é argumento de um núcleo lexical). Em outras palavras, ser argumento é informação lexical, mas ser relação todo/parte não é, sendo, antes, um tipo de relação semântica que reflete a estruturação do próprio objeto denotado.

Logo, os fatos em (13)-(14) justificam a conclusão de que a gramática do português europeu opera o licenciamento de sujeitos numa interface em que está acessível a marcação temática dos argumentos do predicado e a do português do Brasil, numa em que está acessível a sua marcação extensional.

\subsubsection{Deslocamento Sintático de Subconstituinte do Argumento Interno nas Línguas Ameríndias e no PB}

Existe um grande relacionamento entre o processo de deslocamento de um subconstituinte do objeto direto nas estruturas do tipo de (13) no PB e o processo de deslocamento de subconstituinte do objeto direto no tupi, guarani antigo e outras línguas ameríndias. ${ }^{9}$ Vou considerar aqui dados do guarani antigo, por uma simples questão de maior facilidade de acesso, mas eles são do mesmo tipo dos do tupi.

No guarani antigo o subconstituinte que se desloca (e se incorpora ao verbo) é o que designa a parte, ao contrário do que ocorre no português do Brasil, em que o subconstituinte que designa o todo é que se desloca (para a posição de sujeito da sentença). No entanto, há algo em comum resultante desse processo nas duas línguas: o subconstituinte que designa a parte passa a ficar mais próximo ao verbo do que o que designa o todo. Essa posição mais próxima é a posição original de objeto no português do Brasil ([O meu carro [furou o pneu]]) e a morfologia verbal no guarani antigo, como se vê em (15). Em (15b) foi feita a incorporação de ayú (veia), parte do constituinte semântico cyuã rayú (veia do João), na morfologia verbal. Em (15a) ambos os subconstituintes estão formando um sintagma que ocupa a posição de objeto direto. 
$\begin{array}{lllll}\text { a. } & \text { a- } & \text { i- kutúg cyuã } & \text { r- ayú } \\ \text { 1/NOM } & R & \text { ferir João } & \text { R- veia }\end{array}$

(Grannier 2002: 81)

'Eu feri a veia de João'

b. a- h- ayú- kutúg cyuã

(Grannier 2002: 82)

$1 / \mathrm{NOM} \mathrm{R}$ veia ferir João

'Eu feri a veia de João'

Uma conclusão razoável é que há um certo deslocamento (do subconstituinte expressando o todo no português do Brasil e a parte no guarani antigo) licenciado pelo fato de permitir essa maior proximidade em relação ao verbo do subconstituinte expressando a parte. Isso é bem plausível, pois a parte expressa o elemento diretamente afetado pela ação verbal.

\subsection{Semelhanças entre o PB, o Tupi e a Língua Geral Paulista: Acidente ou Influência Estrutural?}

Se é verdade que o português do Brasil, o tupi e a língua geral paulista fazem uso de traços extensionais nas derivações sintáticas, uma propriedade ausente do português europeu, surge uma pergunta: É essa semelhança acidental ou foi o resultado de influência estrutural? Minha resposta é que foi acidental. Isso significa que penso que os fatos que apresentei sobre a categoria pessoa e sobre deslocamento de subconstituinte do objeto direto, apesar de representarem incríveis semelhanças entre todas essas línguas, não são de fato suficientes para mostrar influência estrutural daquelas línguas ameríndias sobre o português no contexto do Brasil Colônia.

Consideremos a gramde similaridade entre as línguas ameríndias e o português do Brasil, com relação às possibilidades de deslocamento de subconstituinte do objeto. Poderia ela ser usada como reforço para a proposta de influência estrutural das línguas ameríndias sobre o português do Brasil? Afinal, os falantes bilingües já estariam operando com tal tipo de deslocamento em sua gramática internalizada. Acho, no entanto, que essa propriedade do português do Brasil pode muito bem ter decorrido de características da configuração da faculdade de linguagem (i.e., da estruturação mental humana relativa à linguagem). Mais claramente, dado o uso pelo português do Brasil de propriedades extensionais para a geração sintática, nada impedia que esses traços passassem a ser usados em quaisquer estruturas em que isso fosse possível, 
sendo uma delas a estrutura com verbos inacusativos, em que, no português, o argumento interno (único argumento desses verbos) pode ocupar tanto a posição de objeto quanto a de sujeito. Como a posição de sujeito fica vaga quando o argumento interno está na posição de objeto, essa vacância licencia o deslocamento para a mesma. O que licenciaria esse deslocamento no português do Brasil é a tendência da língua a fazer ocupar manifestamente a posição de sujeito.

Tomando como base os dados usados neste artigo até agora, a generalização proposta por este trabalho é que o português do Brasil fixou a informação extensional para o licenciamento sintático de argumentos, em contraste com o português europeu, que fixou a informação temática. No contexto brasileiro, dada a aprendizagem do português como segunda língua por adultos aloglotas, o uso da informação extensional era necessário, pois nesse processo de aquisição os falantes não seguem os mesmos passos da aquisição de primeira língua pela criança. Para a criança, mesmo que somente nas fases mais iniciais, há primeiro um domínio fonológico, depois um domínio lexical e em seguida um domínio de sentenças, se bem, é claro, que a aquisição vocabular em geral acompanhe o indivíduo por toda sua vida e a aquisição de novas estruturas sintáticas também possa ocorrer entremeada com a nova aquisição vocabular. Nesse processo, a criança de algum modo adquire informações abstratas relativas à estrutura interna das palavras, como, por exemplo, informação sobre estrutura argumental dos verbos e as coloca em prática na estruturação de sentenças. $\mathrm{O}$ adulto aloglota, ao contrário, tem logo de lidar, simultaneamente, com sentenças, palavras e o sistema fonológico da língua, sem ter a seu favor o estágio inicial da faculdade de linguagem com as propriedades que o caracterizam para a aprendizagem de língua. Dado isso, esse falante adulto não tem como adquirir de imediato todo um conjunto de informações abstratas sobre a estrutura interna das palavras, daí que não constrói seu conhecimento da língua do mesmo modo que o faz a criança ao aprender sua língua nativa. A minha hipótese, então, é que a semelhança é puramente acidental, porque foi conseqüência do processo de aprendizagem em idade adulta e não de influência estrutural direta de uma língua sobre a outra.

Em resumo, a fixação dos traços extensionais para as derivações sintáticas, no caso do português do Brasil, foi fruto do fato de os falantes adultos aloglotas no contexto colonial brasileiro não terem como adquirir, de imediato, as informações abstratas sobre a estrutura das palavras que o 
português europeu usa nas suas derivações sintáticas, tendo de ter recorrido aos traços extensionais.

\section{PROPOSTA DE ANÁLISE}

\subsection{Hipóteses Rejeitadas}

Este trabalho se coloca contra ter havido exclusivamente influência de línguas ameríndias ou de línguas africanas, de qualquer tipo que seja, estrutural ou não, na formação do português do Brasil, assim como se posiciona contra ter havido influência conjunta de tipo estrutural.

Consideremos a hipótese de ter havido influência ameríndia, exclusivamente, ou africana, exclusivamente. Um dos argumentos que já mencionei contra essa hipótese é o do domínio geográfico: não houve bilingüismo relativo a línguas ameríndias ou africanas que cobrisse todo o território brasileiro. O exemplo dado foi o da costa do Rio de Janeiro ao Piauí. Outro caso ilustrativo é o do sul do país. No sul houve a presença indígena, mas numa situação totalmente diferente da que ocorreu em São Paulo e no norte. Considere-se o caso da região que vai do sul do Paranapanema até o Rio Grande do Sul, e desde o Paraguai (rio Paraná) até o litoral de Paraná e Santa Catarina e parte do Rio Grande do Sul. ${ }^{10}$ Nessa longa região habitavam os índios carijó (nome usado no litoral) ou guarani, cuja língua, o guarani, era língua irmá do tupi e do tupinambá. Toda essa região estava sob o domínio da Coroa Espanhola, de modo que não houve contato com o português. No fim do século XVII e no século XVIII é que os portugueses entraram na região, primeiro militarmente e depois por força de tratados entre as duas Coroas, os quais aumentaram as fronteiras do domínio de Portugal. Na época, no território do Rio Grande do Sul havia diversas missões jesuíticas espanholas. Com a chegada dos portugueses, os jesuítas e os cidadãos espanhóis se retiraram para o lado argentino e paraguaio. Houve uma grande revolta indígena, tendo sido os índios combatidos pelos portugueses com seus exércitos. Alguns índios escaparam, mas a maioria morreu. Pequenos grupos ficaram na região, junto com uma população mista de espanhóis e portugueses. Mas não havia quase nenhuma oportunidade de bilingüismo que incluísse o guarani. ${ }^{11}$

Uma outra evidência contra tais influências é o fato de a língua geral amazônica ter perdido a característica do tupinambá de relacionar informação 
sobre pessoa com estrutura sintática e ter, antes, adquirido propriedades da língua portuguesa. Já que foi o português que de fato influenciou a língua geral amazônica, não se pode concluir a favor de uma influência indígena sobre a formação do português do Brasil na região amazônica.

Enfatizei que minha proposta se assemelha, pelo menos parcialmente, à proposta de Naro e Scherre. No entanto, as duas propostas se distinguem em pontos essenciais, que vou procurar resumir. Naro \& Scherre (2004) opõem sua proposta à proposta de crioulização, defendida por Coelho (1880), Guy (1989), Holm (1992) e Baxter \& Lucchesi (1997), e caracterizam a diferença entre os dois tipos de propostas nos seguintes termos. (A) Segundo os adeptos da hipótese da crioulização, as estruturas consideradas típicas do português do Brasil (como a variação no uso da concordância) e que parecem aproximá-lo das línguas crioulas de base lexical portuguesa e dos outros sistemas pidgins/crioulos de maneira geral se devem "a um estágio não documentado de crioulização, resultado do contato maciço com línguas africanas ou com outras línguas tipologicamente diferentes do português, sendo as variações verificadas no Brasil portanto totalmente impossíveis em Portugal". (B) Segundo a hipótese de Naro \& Scherre (2004), "o processo diacrônico que operou no Brasil se deve basicamente à expansão de estruturas já presentes no português europeu que veio para o Brasil no período colonial".

A minha posição consiste numa terceira possibilidade de análise: a formação do português do Brasil foi resultado do contato maciço com falantes de outras línguas, mas isso não invalida a possibilidade de as estruturas em questão já terem existido antes no português europeu. No caso de terem existido, há uma diferença crucial entre as estruturas em Portugal e no Brasil: em Portugal elas são esporádicas e muitas vezes ligadas a fatores lexicais, ao passo que no Brasil elas ganharam sistematicidade. Por exemplo, a variação na concordância no Brasil parece ter caráter mais sintático que lexical e não tem caráter regional (V. dados em Scherre 1988 e 1999), mas, como os dados de Scherre \& Naro (2003) e Naro e Scherre (2004) apontam, no português europeu ou ela se liga a escolhas lexicais, como 'a gente', ou é dialetal. Por outro lado, para Naro \& Scherre (2004), todas as estruturas que caracterizam o português do Brasil são estruturas existentes também no português europeu. Pelo que sei, estruturas como a ilustrada em (13), que repito abaixo, não existem no português europeu: 


\section{(13) O meu carro furou o pneu. (PE: *, PB: OK)}

Concluo que a mudança que ocorreu no português no contexto brasileiro não foi um caso de crioulização, mas tampouco foi um caso de simples expansão, i.e, ampliação do uso, de estruturas já presentes no português europeu do período colonial brasileiro. A mudança pode tanto sistematizar o uso de estruturas que tinham uso restrito em Portugal quanto criar novas estruturas.

A minha análise se diferencia da de Naro e Scherre também na explicação para a sistematicidade da variação de concordância que ocorreu no Brasil. Para eles (NARO; SCHERRE, 2004), "essas estruturas variáveis floresceram e se expandiram por causa da ruptura da norma no processo de formação de uma nova comunidade de fala". Acho que essa descrição dos fatos não é explicativa. Por exemplo, consideremos os casos de preenchimento simultâneo das posições de sujeito e objeto com subconstituintes do argumento interno. Esses casos são restritos a orações com verbos inacusativos. Por que os falantes teriam "escolhido" os verbos inacusativos, e somente eles, para predicado dessas estruturas inovadoras? Certamente, os traços abstratos dos verbos inacusativos são responsáveis pelo licenciamento dessas estruturas. Mantendo igualmente esse conceito de traço abstrato, minha hipótese é que a variação da concordância no português do Brasil ganhou tanta sistematicidade em virtude de um novo funcionamento na língua (qualquer que seja ele) dos traços que subjazem ao plural.

Igualmente, não me satisfaz a descrição do português brasileiro como "apenas o português liberado das amarras de uma norma tradicional de uma comunidade de fala estável e conseqüentemente livre para manter e desenvolver o uso de estruturas e formas de menor prestígio, já existentes nas variedades sociais e geográficas do português europeu que veio para o Brasil com os próprios portugueses". Não me satisfaz porque não explica (a) a 'escolha' de certos itens, e somente eles, para certas estruturas inovadoras, como é o caso de verbos inacusativos na estrutura (13), (b) a 'escolha' de certo tipo de item lexical para preenchimento da posição não-argumental de sujeito - Por que não ocorre expletivo manifesto no português do Brasil como ocorre em certas regiões de Portugal (Ele chove), havendo no português do Brasil um outro tipo de preenchimento para posições de expletivo, como apontado por E. Duarte (2000)? -, ${ }^{12}$ (c) os fatos de gramaticalização, que passo a descrever na próxima seção. 
Adicionalmente, quero me posicionar contra a idéia de ser possível existir uma evolução lingüística que não seja natural. Neste ponto, estou voltando à argumentação em Guy (1981), que resumi na Introdução, e defendendo que mesmo as línguas crioulas têm, necessariamente, de resultar de uma evolução natural, de acordo com princípios da faculdade de linguagem. O conceito de língua crioula tem de ser definido em termos de suas propriedades lingüísticas, e não, a meu ver, na alegação de que seria um desenvolvimento não-natural. ${ }^{13}$ No caso do português do Brasil, não houve, nitidamente, a criação de uma língua crioula. O que houve, se minha análise tiver algum fundo de verdade, foi uma mudança no tipo de traços usados nas gerações de expressões lingüísticas. Nesse sentido, minha análise da mudança faz uma proposta concreta a respeito do que foi a deriva na evolução que ocorreu no português no território brasileiro - a mudança decorreu do uso de traços extensionais dos itens para a geração sintática, e não de traços ligados à estrutura intensional das palavras (incluindo-se aí a estrutura argumental).

\subsection{Deriva e Gramaticalização}

No Capítulo 7 de seu livro Language, Sapir introduziu o conceito de deriva (drift), caracterizado como a direção precisa e determinada que segue a evolução lingüística, e analisou a substituição de whom por who em inglês como a conseqüência de três derivas: (a) tendência a suprimir a distinção entre sujeito e objeto, (b) tendência a uma ordem fixa das palavras na frase, determinada pela relação sintática das palavras, (c) tendência ao desenvolvimento de palavras sem variação.

Eu gostaria de tomar o conceito de deriva como relativo ao uso de traços no licenciamento das derivações. Nessa linha, a tese que defendo é que a tendência evolutiva seguida pelo português, no contexto brasileiro, foi direcionada pelo licenciamento dos argumentos sintáticos com uso dos traços de interpretação referencial. ${ }^{14}$ Essa já era uma propriedade das línguas indígenas brasileiras. Caso a influência para a formação do português do Brasil tenha sido conjunta, essa semelhança entre o português do Brasil, o tupi e a língua geral paulista (além de outras línguas indígenas brasileiras) foi somente acidental. Não importava a língua dos aloglotas. Importava a situação de aquisição de segunda língua em idade adulta. Se isso é verdade, vale a tese da gramaticalização, que defendi em outra oportunidade (LOBATO, 2001): a mudança com efeito de 
gramaticalização ocorre em decorrência do processo de aprendizagem como segunda língua em idade adulta e em virtude de nessa situação os aprendizes não fazerem o percurso das crianças em aquisição de língua materna (primeiro aquisição de palavras e em seguida construção de frases com as mesmas), ocorrendo, antes, uma aprendizagem de frases juntamente com palavras. O que se entende por gramaticalização neste contexto? Defendi que a linearização das expressões nominais sujeito e objeto é licenciada no português europeu por verificação de traço temático e no português do Brasil, por verificação do traço extensional. Numa gramática como a do português europeu, em que há uma propriedade temática, que é propriedade do nível lexical, que é verificada na sintaxe para licenciamento da linearização da expressão nominal que a porta, é uma propriedade do nível lexical que é acionadora do posicionamento. Mas, numa gramática como a do português do Brasil, em que é o traço extensional nominal que precisa ser verificado para linearização de expressão nominal, já que traço extensional é traço categorial, e traço categorial é construtor de estrutura, é uma propriedade do nível da construção de estrutura que é licenciadora da derivação. Nessa abordagem, o processo de gramaticalização pode, então, ser entendido como um processo de linearização sintática acionado por traço estrutural. Como os traços extensionais são de tipo estrutural, pode também ser entendido como dizendo respeito a licenciamento de linearizacão no nível extensional, e não intensional.

Há evidência de ter havido um processo de gramaticalização no português do Brasil. A mudança no sistema pronominal clítico é evidência nesse sentido: no português do Brasil houve fixação da posição pré-verbal para os clíticos, em contraste com sua ocorrência pré- e pós-verbal no português europeu (sem considerar a mesóclise). Essa cristalização de posição estrutural encontra uma explicação plausível na hipótese de gramaticalização: elementos gramaticalizados têm posicionamento estrutural rígido, cristalizado. A mudança no sistema clítico, quanto à redução das possibilidades de interpretação de pessoa - de três diferentes pessoas para duas, como apontado -, também condiz com a tese da gramaticalização, dada a conhecida diferença numérica entre elemento lexical e elemento gramatical. No nosso caso, não podemos falar (pelo menos ainda) em redução do efetivo de elementos, mas há, de qualquer modo, redução do número de interpretações, o que, igualmente, recebe explicação como efeito de gramaticalização.

Esistem outras evidências, independentemente motivadas, a favor dessa tese. Uma delas é o fato de ter havido no português do Brasil perda da informação 
cultural associada ao item lexical você. Esse item deriva, historicamente, da expressão de tratamento Vossa Mercê. Vossa Mercê implica uma relação social assimétrica entre falante e ouvinte - o falante se situa em posição hierárquica inferior à do interlocutor. Com a lexicalização da expressão de tratamento sob a forma você, houve, no português europeu, uma inversão da relação social assimétrica: em Portugal, você implica que o falante se situa em posição hierárquica mais alta do que a do interlocutor. ${ }^{15}$ Esse tipo de informação cultural só pode se situar no plano da estrutura LC desse pronome. No português do Brasil, perdemos essa interpretação da estrutura LC de você, e esse pronome é usado sem implicação de assimetria social. ${ }^{16}$ Houve então perda de informação semântica, o que bem caracteriza o processo comumente identificado como 'bleaching', típico do fenômeno de gramaticalização.

Lorenzo Vitral (1996, 2000) analisa o processo de redução fonológica nas formas pronominais do português do Brasil em termos de gramaticalização. Essa perspectiva de análise vem bem ao encontro da proposta que estou defendendo, e esses processos de redução fonológica, que envolvem também outros pronomes (por exemplo, 'es' por 'eles') são um outro tipo de evidência independente em favor da tese de gramaticalização.

Finalmente, os fatos de concordância de número dão suporte à tese da gramaticalização, em virtude de a variação que existe no português europeu contemporâneo ou existiu em estágios anteriores da língua não ser sistemática como é no português do Brasil contemporâneo (cf. dados em Naro \& Scherre 2000b). A regularidade dos padrões da variação no português do Brasil é um fato surpreendente, atestado em todos os diferentes estudos sobre essa questão em diferentes regiões do país, fato mostrado em Scherre (1999). Além disso, a variação é significativa em termos estatísticos, o que não ocorre no português europeu. Esses fatos são compatíveis com a tese da gramaticalização. É em virtude de o licenciamento extensional ter se gramaticalizado no português do Brasil que a concordância de número está em variação. A concordância regular, do tipo existente no português europeu, só é compatível com uma gramática em que os traços extensionais são licenciados na sintaxe nominal. No português do Brasil, como vimos, os dados apontam para um outro tipo de gramática: uma gramática com verificação da interpretação extensional pela sintaxe oracional. Uma hipótese viável é que decorre daí a variação, sendo ela resultado de um processo de mudança lingüística, como já tinha sido apontado por Scherre (1988). 


\section{OBSERVAÇÕES FINAIS}

Este trabalho apresentou dados empíricos que mostram que o português do Brasil possui a propriedade de usar traços extensionais para o licenciamento da linearização dos argumentos sintáticos, e que essa propriedade é compartilhada com o tupi e a língua geral paulista (além de outras línguas indígenas brasileiras), mas não com o português europeu.

Apesar disso, o trabalho defende como mais provável a alternativa de análise de que a formação da gramática do português do Brasil resultou da situação de contato lingüístico do período colonial, quando o português foi adquirido por grande parte da população adulta do país como segunda língua, e isso teria levado ao uso de traços extensionais para a derivação sintática. Essa conclusão se coaduna com as observações de Mattos e Silva (2000, 2003) a respeito das condições sociohistóricas condicionantes na formação do português do Brasil.

Segundo essa abordagem da questão, o fato de diferentes variedades do português europeu terem sido trazidas para a colônia não foi fator crucial para a mudança. Nas palavras de Teyssier (1997, p. 78), "o povoamento europeu se fez a partir de todas as regiões de Portugal" e, nessa situação de coexistência de diferentes variedades, houve um processo de padronização, com "eliminação de todos os traços marcados dos falares portugueses do Norte e por generalização das maneiras não marcadas do Centro-Sul". Isso pode muito bem ter ocorrido, mas o que importou para a mudança, segundo a hipótese deste artigo, foi, repito, o processo de aquisição do português como segunda língua por uma população adulta. ${ }^{17}$

Quero ressaltar aqui a importância do fator interno nesse processo de mudança, causado pela aprendizagem como segunda língua em idade adulta. A apresentação de um fator interno é o que falta às demais abordagens que têm sido feitas da questão. O ponto crucial da explicação, como a vejo, é que, para a população adulta aloglota, a aprendizagem da língua não se faz, como já dito, a partir da aprendizagem de palavras e em seguida de frases. Ao contrário, a aprendizagem se faz a partir de frases. Um fato importante que procurei demonstrar é a relevância da informação lexical para a derivação sintática, no português europeu. $O$ dado ilustrado foi o da projeção de sujeito e objeto na estrutura oracional. Outro dado é o da importância da estrutura lexical para a colocação dos pronomes. Martins (1992) aponta que o sujeito que é relevante 
para forçar a ênclise no português europeu contemporâneo não é do tipo quantificacional. Ela ilustra essa afirmação com o seguinte par:

(16) a. Muitos amigos meus queixaram-se às autoridades.

b. Muitos amigos meus se queixaram às autoridades.

Essas duas sentenças, ambas gramaticais, têm interpretação semântica diferente. (16a) "é verdadeira se um grande número de pessoas que são meus amigos se queixaram às autoridades." Mas (16b) "é verdadeira somente se uma grande proporção dos meus amigos se queixou às autoridades. O número de amigos que eu tenho é irrelevante para avaliar a verdade de (16a), mas indispensável para avaliar a verdade de (16b). Só (16b) tem a leitura proporcional característica dos quantificadores".

(16') a. Muitos amigos meus queixaram-se às autoridades.

$\mathrm{PE}=$ um grande número de pessoas que são meus amigos se queixaram (Leitura Referencial)

b. Muitos amigos meus se queixaram às autoridades.

$\mathrm{PE}=$ uma grande proporção dos meus amigos se queixou (Leitura Quantificacional)

A evidênciaéque, como ilustrado em (17), uma relativa não restritiva pode qualificar o sujeito na oração com ênclise, mas não na oração com próclise. Isso se deve ao fato de as relativas não restritivas exigirem um antecedente referencial:

(17) a. Muitos amigos meus, que são antropólogos, queixaram-se às autoridades.

b. *Muitos amigos meus, que são antropólogos, se queixaram às autoridades.

Dado o caráter lexical das condições para a colocação pronominal no português europeu, e pressupondo que havia influência lexical também na colocação pronominal no português clássico, não havia, para a população de adultos aloglotas do Brasil Colônia, como adquirir informação sobre colocação pronominal. ${ }^{18}$

A importância da informação lexical se faz ver também no vocalismo português. Por exemplo, como nos informa Teyssier (1997, p. 42), a distinção que o português europeu faz entre timbres abertos e fechados para as vogais tônicas 
$a, e$ e $o$ seguidas de consoante nasal iniciante de sílaba é de base lexical. Por exemplo, nas palavras em que etimologicamente a vogal $a$ seguida de consoante nasal iniciante de sílaba resulta da contração de duas vogais, ela tem timbre aberto, ao passo que quando etimologicamente corresponde a uma vogal única tem timbre fechado. Assim é que em ga-anha > ganha (verbo) e ga-anho $>$ ganho (substantivo) o a mantém um timbre aberto, apesar da consoante nasal seguinte iniciante de sílaba. Mas em cama, cana e banho, onde etimologicamente se tem uma vogal singela, e não um encontro de vogais, a vogal $a$ tem timbre fechado. Essa distinção entre vogais com timbre aberto e fechado antes de consoante nasal iniciante de sílaba se perdeu inteiramente no português do Brasil, onde nesse contexto as vogais são sempre nasalizadas. ${ }^{19}$ Naturalmente, não havia, para uma população adulta adquirindo o português como segunda língua, como adquirir um vocalismo que depende de informação lexical tão abstrata (informação sobre a estrutura fonológica subjacente das palavras).

Concluo este artigo sugerindo que, paralelamente a esta linha de investigação que levei a cabo, também o estudo da hipótese de influência das línguas africanas deveria ser aprofundado, com análises lingüísticas comparativas. Uma questão a ser examinada, por exemplo, é a propriedade das línguas banto (pelo menos as contemporâneas) de serem línguas de sujeito pronominal nulo, diferentemente do português do Brasil, que se tornou uma língua de sujeito pronominal manifesto, ao contrário do português europeu. Esse desenvolvimento gramatical do português do Brasil não seria compatível com a tese da influência direta estrutural das línguas africanas, caso as línguas banto também fossem de sujeito pronominal nulo na época em que foram trazidas para o Brasil.

\section{NOTAS}

* Ofereço este artigo ao Prof. Aryon Rodrigues, um modelo de pesquisador e cientista e um exemplo de vida dedicada ao estudo de línguas indígenas brasileiras e ao incentivo a esse estudo, como uma homenagem no ano de seu octagésimo aniversário. Agradeço a ele e a Daniele Grannier pelas cruciais observações a respeito de versões anteriores deste trabalho e por esclarecimentos a respeito de dados do tupi, das línguas gerais e do guarani antigo. Agradeço a Marta Scherre por referências e informações relativas à proposta de Naro e Scherre sobre a formação do português do Brasil. Isso não torna nenhum deles responsável pelas afirmações que faço, que são de minha inteira responsabilidade. 
${ }^{1}$ Este artigo também será publicado em: SILVA, Denize Elena G. da (Ed.). Língua, Gramática e Discurso. Goiânia: Cânone.

${ }^{2}$ Os dados aqui apresentados sobre as línguas gerais foram extraídos de Rodrigues (1996). A leitura desse excelente estudo é essencial para uma compreensão dos fatos relativos a essas línguas.

${ }^{3}$ VIEIRA, Pe. Antônio 1856. Obras várias, v. I: 249, Lisboa. Apud Buarque de Holanda 1995, p. 122-123.

${ }^{4} \mathrm{Na}$ verdade, o texto de Mattos e Silva (2000) deixa dúvidas sobre se de fato ela considera que as línguas indígenas e línguas gerais foram fatores produtores da mudança. De um lado ela afirma (p. 19, itálicos meus) que "[e]m trabalhos anteriores [...] tenho proposto que no cenário colonial os "atores" lingüísticos principais em concorrência seriam: as línguas gerais indígenas, o português europeu e o que tenho designado de português geral brasileiro em formação, que teria como falantes principais os indígenas remanescentes que se integraram à sociedade nacional e os africanos e afro-descendentes que, num crescendo, serão de $42 \%$, sobre uma população de $100.750 \mathrm{~h}$ ao fim do século XVI [...]". Também afirma (p. 13, italico meu) que "a 'voz' africana e dos afro-descendentes, adquirindo necessariamente [...] a língua dos colonizadores, a portuguesa, como língua segunda, na oralidade do quotidiano diversificado e multifacetado, sem o controle normativizador explícito da escolarização, reestruturou o português europeu [...]." Adiante (p. 23, itálico meu), afirma: "é esse segmento numeroso e operante - os africanos e afro-descendentes - o agente principal da difusão do português no território brasileiro, na sua face majoritária, a popular ou vernácula.

${ }^{5}$ Apesar de se ouvir com freqüência que o português do Brasil é uniforme ao longo de toda a sua extensão geográfica, essa afirmação tem de ser relativizada, pois verificam-se às vezes diferenças regionais marcantes, até mesmo sintáticas. Cito a permanência, no Rio Grande do Sul, da propriedade do português europeu de expressar o artigo depois do quantificador em uma construção como Todo o homem é mortal, que se caracteriza pela ausência de artigo em outras regiões, como a sudeste, em que a forma gramatical é Todo homem é mortal.

${ }^{6}$ Levando em conta a caracterização de morfema relacional em Grannier (2005), nos exemplos (4) não seria adequada a tradução de $i$ - por 'a ele'. Estou mantendo essa tradução por uma questão de clareza da exposição. A análíse do morfema $i$ - como relacional é a tendência atual de análise entre os estudiosos de línguas indígenas brasileiras. 
${ }^{7}$ A gramática do português coloquial do Brasil também se distingue da do português formal do Brasil quanto ao inventário e uso dos clíticos. Por exemplo, na variante formal ocorre a forma $o$ como $3^{\mathrm{a}}$ pessoa.

${ }^{8}$ Estou usando a distinção entre extensão e intensão, comum em semântica: a extensão diz respeito à aplicação do item e a intensão, a seu sentido. Como as categorias gramaticais, na sua definição nocional, dizem respeito à aplicação dos itens (por exemplo, nomes se referem a entidades, verbos a eventos), estou considerando que são de tipo extensional. Por sua vez, tomo os traços temáticos como intensionais porque estão intimamente ligados à própria definição conceitual dos predicados (por exemplo, comer é ação de mastigação e deglutição de agente sobre tema).

${ }^{9}$ Agradeço a Daniele Grannier (c. p.) por ter chamado a minha atenção para esse relacionamento.

${ }^{10}$ No relato que faço sobre os guarani reproduzo informação recebida de Aryon Rodrigues (c. p.).

${ }^{11}$ Se tivesse havido bilingüismo, teríamos a mesma situação ocorrida com o tupi e a língua geral paulista, porque o guarani possuía as mesmas propriedades que apontei para aquelas línguas. Considere-se, por exemplo, o guarani antigo, que correspnde às variedades do guarani faladas e documentadas nos séculos XVII e XVIII nas regiões que correspondem atualmente ao Paraguai, ao norte da Argentina (Misiones) e ao oeste do Paraná e Rio Grande do Sul. Grannier (2002, 2005), em cuja análise baseio minhas observações, examinou especificamente a variedade do guarani descrita pelo Padre Antonio Ruiz de Montoya, no século XVII e falada nas missões dos jesuitas da antiga província de Guairá, situadas na atual região do noroeste do Paraná. O guarani antigo fazia uma correlação entre seleção de estrutura sintática e morfológica, de um lado, e seleção de pessoa gramatical, de outro. Por exemplo, nas estruturas transitivas, se o objeto é pronominal (analisado como clítico por Gannier), só pode ser de $1^{\mathrm{a}}$ ou $2^{\mathrm{a}}$ pessoa (porque na língua só existem formas pronominais livres de $1^{\mathrm{a}} \mathrm{e} 2^{\mathrm{a}}$ pessoas, como já visto para o tupi). Isso está representado em (i), onde a estrutura à esquerda da flecha, que contém um objeto clítico, implica a interpretação da pessoa do objeto como à direita da flecha.
(i) $\mathrm{OCl}[\mathrm{R}-\mathrm{V}]_{\mathrm{V}} \mathrm{S}$
$=>$
O $1 / 2$

Nessa estrutura, assim como nas demais onde ocorre, R é símbolo de morfema relacional. 
Por sua vez, na interpretação da pessoa gramatical do clítico como de $1^{\mathrm{a}}$ ou $2^{\mathrm{a}}$ pessoa, na estrutura (i), existe uma relação de implicação entre as pessoas do sujeito e do objeto. Se o sujeito é de $2^{\mathrm{a}}$ pessoa, o objeto é de $1^{\mathrm{a}}$, necessariamente, e se o sujeito é de $3^{\mathrm{a}}$, o objeto pode ser de $1^{\mathrm{a}}$ ou $2^{\mathrm{a}}$. Além disso, quando o sujeito é de $2^{\mathrm{a}}$, é necessariamente manifesto. Quando é de $1^{\mathrm{a}}$, é optativo. Isso está resumido em (ii):

(ii) $\mathrm{OCl}[\mathrm{R}-\mathrm{V}]_{\mathrm{V}} \mathrm{S}$

$1<=\quad 2$ (necessariamente manifesto)

$1 / 2<=3$ (optativamente manifesto)

Essas estruturas estão ilustradas em (iii)-(iv):

(iii) cye $[\mathrm{r}-\text { enõy }]_{\mathrm{V}}$ epé OCl1 $[\mathrm{R}$ chamar $]$ você me chamar você 'Você me chama'(iv)

a. cyuã cye [r- enõy] João OCl1 [R chamar]

'João me chama'

b. cyuã ne [r- enõy] João OCl2 [R chamar]

'João te chama'

Além desses dois tipos de relações, existem também os seguintes:

(a) Se o objeto é prefixal, só pode ser de $2^{\mathrm{a}}$ e o sujeito é de $1^{\mathrm{a}}$ :

$$
[()-\mathrm{V}] \mathrm{S} \quad \Rightarrow \quad \mathrm{O} 2 \text { e } \mathrm{S} 1
$$

Assim, a estrutura em (v) significa 'eu te chamo', mesmo que o sujeito esteja não manifesto.

(v) (cye) [oro-enõy $]_{\mathrm{v}}$ [2sg/O-chamar] (eu) [te-chamar] 'Eu te chamo'

(b) Se o sujeito é prefixal, pode ser de $1^{\mathrm{a}}, 2^{\mathrm{a}}$ ou $3^{\mathrm{a}}$, e o objeto é de $3^{\mathrm{a}}$ :

(S) $[\mathrm{S} 1 / 2 / 3-\mathrm{R}-\mathrm{V}] \quad=>\mathrm{O} 3$

Inversamente, se o objeto é de $3^{\text {a }}$, e se há prefixo de sujeito no verbo, o sujeito pode ser de $1^{\mathrm{a}}, 2^{\mathrm{a}}$ ou $3^{\mathrm{a}}$.

(vi) (cyé) [a- h- enõy] cyuã $1 \mathrm{~S} \quad$ [1S R chamar] João 'Eu chamo João'

${ }^{12}$ (Duarte 2000, p. 31ss) mostrou ocorrer uso de sujeito referencial no português do Brasil em contextos de ocorrência de expletivos manifestos em línguas que os têm:

a) Em contextos existenciais e impessoais: uso do 'você' arbitrário com 'ter' e 'ver': Você não tem mais clientela no centro da cidade. (= Não se tem mais clientela ...) Você vê muito concreto na tua frente (= Há muito concreto). 
b) Com verbos de alçamento: licenciamento de sujeito manifesto na posição de sujeito de parecer e na posição do verbo encaixado flexionado:

Parece que vocês não pensam a sério na vida.

Vocês parecem não pensar a sério na vida.

Vocês parecem que pro/vocês não pensam a sério na vida.

c) Alçamento para sujeito da matriz, do objeto de oração infinitiva:

Eles valem a pena ser salvos cv.

Essas coisas levam tempo pra aprender cv.

d) Alçamento para sujeito da matriz, de DP subconstituinte do argumento interno e expressando o todo:

Sempre que ela come carne de porco, ela solta umas bolinhas na mão.

e) Manifestação de 'isso' na posição de sujeito em estruturas existenciais:

Isso era em torno de dez pessoas.

${ }^{13}$ Roberts (1999, p. 316) associa a formação de línguas crioulas ao caráter defectivo dos gatilhos sintáticos e à falta de gatilhos morfológicos no conjunto de dados da experiência engatilhadora da aquisição, o que leva à fixação de valores não-marcados para os parâmetros (isto é, leva à fixação de traços fracos para os núcleos funcionais). Lightfoot (1999, p. 448) associa essa formação à falta de robustez de pistas na experiência lingüística engatilhadora da fixação de parâmetros.

${ }^{14}$ Dada a exemplificação que estou usando, neste artigo estou dando ênfase aos traços extensionais. No entanto, no processo de mudança que houve no português do Brasil foram acionados traços ligados à forma em geral, estanto aí incluídos os traços extensionais, vs traços ligados ao conteúdo semântico dos itens. Falar em traços ligados à forma permite cobrir os traços relativos à formação silábica, por exemplo, que também se gramaticalizou no português padrão do Brasil.

${ }^{15}$ Cunha \& Cintra (1985, p. 284) observam que, ao contrário do que ocorre no Brasil, em Portugal não é possível "usar você de inferior para superior, em idade, classe social ou hierarquia”, só sendo possível usá-lo como tratamento de igual para igual ou de superior para inferior (em idade, em classe social, em hierarquia). Acrescentam que "só excepcionalmente - e em certas camadas sociais altas - aparece usado como forma carinhosa de intimidade." Estou generalizando os fatos do PE além da observação de Cunha \& Cintra, em virtude de minha experiência pessoal, que tem mostrado um certo constrangimento dos portugueses ao serem tratados por 'você' em condições de igual para igual, havendo casos de pedido explícito para mudança de escolha do pronome, como relatado 
por Clóvis Santos (c.p.). A mudança é, no entanto, problemática para os brasileiros que têm você como a forma natural de segunda pessoa, pois o uso de 'tu' não é natural em sua gramática.

${ }^{16}$ Essa perda está intimamente ligada à perda da oposição entre tu e você. Os falantes que mantêm o uso das duas formas sentem uma interpretação mais afetiva em $t u$, como apontado por Suzana Cardoso (c. p.).

${ }^{17}$ Essa questão de não-marcação teria de ser aprofundada. Como explicar que tenha se mantido no Rio de Janeiro, entre outras regiões, o $s$ e $z$ chiantes, provavelmente por influência da presença lusitana com a vinda da Corte para o Brasil no início do século XIX? Esse traço, a meu ver, seria um traço marcado, e é um traço que existe no Centro-Sul de Portugal.

${ }^{18}$ Desde o português arcaico, os contextos de próclise obrigatória são os mesmos que no português contemporâneo. O que mudou foram os contextos de ênclise obrigatória. V. Martins (1994).

${ }^{19}$ A vogal $a$ com timbre fechado é uma vogal com os traços [-alto] e [-baixo] e a com timbre aberto, com os traços [-alto] e [+baixo], portando ambas o traço [nasal] (Viana 1990, p. 236).

Observe-se que essa distinção se faz até hoje no português europeu, onde as formas de $1^{\text {a }}$ pessoa plural do presente do indicativo e do pretérito perfeito da primeira conjugação (ambas grafadas do mesmo modo; p.ex., cantamos) se distinguem pelo timbre (fechado para o presente do indicativo e aberto para o pretérito perfeito). O português do Brasil não faz tal distinção, e mantêm a nasalização para ambas as formas.

\section{REFERÊNCIAS BIBLIOGRÁFICAS}

ANCHIETA, Joseph de (1595). Arte de grammatica da lingua mais usada na costa do Brasil. Coimbra. [Edição fac-similar: Artes de Gramática da Língua mais usada na Costa do Brasil. $7^{a}$ edição. São Paulo: Loyola. 1990.]

BAXTER, Alan N.; LUCCHESI, Dante. A relevância dos processos de pidginização e crioulização na formação da língua portuguesa no Brasil. Estudos lingüísticos e literários. Salvador. Universidade Federal da Bahia. $\mathrm{N}^{\circ}$ Especial: 65-83, 1997. 
BUARQUE de HOLANDA (1995). A língua geral em São Paulo. In: Raízes

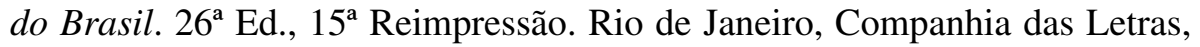
pp. 122-133. [Primeira publicação em 1945, Estado de São Paulo.]

CAMARA Jr., J. Mattoso. História e Estrutura da Língua Portuguesa. 3. ed. Rio de Janeiro: Padrão, 1979.

COELHO, Francisco Adolpho (1880). Os dialectos românicos ou neolatinos na África, Ásia e América. Boletim da Sociedade de Geografia de Lisboa. (Reproduzido em Barbosa, J. Morais (Org.). Estudos Lingüísticos Crioulos. Lisboa: Academia Internacional de Cultura Portuguesa, 1967. p. 129-196.

DUARTE, Eugênia (2000). The loss of the Avoid Pronoun Principle in Brazilian Portuguese. In: Kato \& Negrão (Eds.). Brazilian Portuguese and the Null Subject Parameter. Frankfurt am Main, Vervuert; Madrid, Iberoamenricana, p. 17-36.

GRANNIER. Daniele M. Aspectos da Morfossintaxe do Guarani Antigo. 2002. Tese (Doutorado) - UFAL, Maceió. (Inédita)

. A natureza dos prefixos relacionais em Guarani Antigo. In: RODRIGUES, A.; CABRAL, A.S. (Eds.). Novos Estudos sobre Linguas Indígenas. Brasília: Editora UnB, 2005. p. 129-140.

GUY, Gregory R. Linguistic Variation in Brazilian Portuguese. 1981. Tese (Doutorado) - University of Pennsylvania.

- On the nature and origins of popular Brazilian Portuguese. In: Estudios sobre Espanhol da América Y Lingüistica Afroamericana. Bogotá, 1989. p.226-244.

HOLM, John. Vernacular Brazilian Portuguese: a semi-creole. In: D'ANDRADE, E.; KIHM, A. (Eds.). Actas do Colóquio sobre "crioulos de base lexical portuguesa”. Lisboa: Colibri, 1992. p. 37-66

LIGHTFOOT, David. Creoles and Cues. In: Michel, DeGRAFF (Ed.). Language Creation and Language Change: Creolization, Diachrony, and Development. Cambridge, Mass.: MIT Press, 1999. p. 431-452.

LOBATO, Lucia M. P. "Sobre as Origens do Português do Brasil: Proposta de uma Nova Abordagem". Conferência proferida durante a $53^{a}$ Reunião Anual da SBPC. UFBA, Salvador, 2001.

MARTINS, Ana Maria. Clíticos na História do Português. 1994. Tese (Doutorado) - Universidade de Lisboa. 
MARTIUS, Carl F. P. von (1867). Würtersammlung brasilianischer Sprachen /Glossaria linguarum Brasiliensium / Glossarios de diversas lingoas e dialectos que fallao os Indios no imperio do Brazil (Beiträge zur Ethnographie und Sprachenkunde Amerika's zumal Brasiliens, vol. II) Leipzig, Friedrich Fleischer.

MATTOS E SILVA, Rosa Virgínia. Uma interpretação para a generalizada difusão da língua portuguesa no território brasileiro. Gragoatá. 9 (2): p. 11-27, 2000.

- Fatores sociohistóricos condicionantes na formação do português brasileiro: em questão o propalado conservadorismo da língua portuguesa no Brasil. Revista da ANPOLL, v. 14, p. 205-232, 2003.

MATTOSO, Kátia. Ser escravo no Brasil. 3. ed. São Paulo: Brasiliense, 1990. MUSSA, Alberto. O Papel das Línguas Africanas na História do Português do Brasil. 1991. Dissertação (Mestrado) - UFRJ.

NARO, Anthony. The social and structural dimensions of a syntactic change. Language, v. 57, p. 63-98, 1981.

NARO, Anthony J.; SCHERRE, M. Marta P. Sobre as origens do português popular do Brasil. Delta 9, n. Especial, p. 437-454, 2000a.

. Variable Concord in Portuguese: the situation in Brazil and Portugal. In: McWHORTER, John (Ed.). Language Change and Language Contact in Pidgins and Creoles. Amsterdam/Philadelphia: John Benjamins, 2000b.p.235255.

- Sobre as origens do português brasileiro: retrospectiva de um garimpo. Comunicação apresentada ao XX Encontro Nacional da Associação Portuguesa de Lingüística, 2004. (Texto a ser publicado nas Actas do Encontro.)

ROBERTS, Ian. Verb Movement and Markedness. In: DeGRAFF, Michel (Ed.). Language Creation and Language Change: Creolization, Diachrony, and Development. Cambridge, Mass.: MIT Press, 1999. p. 287-327.

RODRIGUES, Aryon D. (1986). Línguas Brasileiras. São Paulo, Loyola. —. As Línguas Gerais Sul-Americanas. Papia, 4(2): p. 6-18, 1996.

SAPIR, Edward. Language. Nova Iorque: Harcourt, 1921. 
SCHERRE, M. Marta P. Reanálise da Concordância Nominal em Português. 1988. Tese (Doutorado) - UFRJ. (Inédita).

- A sociolingüística laboviana no Brasil: o passado, o presente e o futuro. Goiânia, UFG, 1999. Trabalho apresentado no II Seminário Nacional de Lingüística e Língua Portuguesa.

SCHERRE, M. Marta P.; NARO, Anthony J. Sobre as origens estruturais do português brasileiro: o garimpo continua. Brasília, 2003. Manuscrito de palestra feita na UnB.

TEYSSIER, Paul. História da Língua Portuguesa. 7. ed. Trad. Celso Cunha. Lisboa: Sá da Costa, 1997. [Tradução de Histoire de la Langue Portugaise. Coleção Que Sais-Je? Paris: Presses Universitaires de France, 1980.]

VIANA, Maria do Céu. Traços Fonéticos. In: MIRA MATEUS, Maria Helena et alii. Fonética, Fonologia e Morfologia do Português. Lisboa: Universidade Aberta, 1990. p. 225-267.

VITRAL, Lorenzo. A forma cê e a noção de gramaticalização. Revista de Estudos da Linguagem, v.5, p. 115-124, 1996.

—. Gramaticalização de 'você': um processo de perda de informação semântica? Filologia e Lingüística Portuguesa, v. 3, p. 55-64, 2000. 